\title{
Tocopherol Derivative TFA-12 Promotes Myelin Repair in Experimental Models of Multiple Sclerosis
}

\author{
Benoit Blanchard, ${ }^{1,2,3}$ Tony Heurtaux ${ }^{4}$ Corina Garcia, ${ }^{1,2,3}$ Natalia M. Moll, ${ }^{1,2,3}$ Céline Caillava, ${ }^{1,2,3}$ Luc Grandbarbe ${ }^{4}$ \\ Armelle Klosptein, ${ }^{1,2,3}$ Christophe Kerninon, ${ }^{1,2,3}$ Magali Frah, ${ }^{1,2,3}$ Djalil Coowar, ${ }^{5}$ Anne Baron-Van Evercooren, ${ }^{1,2,3,6}$ \\ Eleonora Morga, ${ }_{4}^{4}$ Paul Heuschling, ${ }^{4}$ and Brahim Nait Oumesmar ${ }^{1,2,3,6}$ \\ ${ }^{1}$ Institut National de la Santé et de la Recherche Médicale U.975, Centre de recherche de l'Institut du Cerveau et de la Moelle Epinière, 75013 Paris, France, \\ ${ }^{2}$ Université Pierre et Marie Curie Paris 6, UMR-S975, 75013 Paris, France, ${ }^{3}$ CNRS UMR 7225, 75013 Paris, France, ${ }^{4}$ Life Sciences Research Unit, Laboratoire \\ de Neurobiologie, Faculté des Sciences, de la Technologie et de la Communication, Université du Luxembourg, L-1511 Luxembourg, ${ }^{5}$ AxoGlia Therapeutics, \\ L-1511 Luxembourg, and ${ }^{6}$ Assistance Publique-Hôpitaux de Paris, Hôpital Pitié-Salpêtrière, Fédération des Maladies du Système Nerveux, 75013 Paris, \\ France
}

Multiple sclerosis (MS) is an inflammatory disease of the CNS that is associated with demyelination and axonal loss, resulting in severe neurological handicap. Current MS therapies mostly target neuroinflammation but have only a little impact on CNS myelin repair. Progress toward treatments that enhance remyelination would therefore represent major advances in MS treatment. Here, we examined the ability of TFA-12, a new synthetic compound belonging to tocopherol long-chain fatty alcohols, to promote oligodendrocyte regeneration and remyelination in experimental models of MS. We showed that TFA-12 significantly ameliorates neurological deficit and severity of myelin oligodendrocyte glycoprotein-induced experimental autoimmune encephalomyelitis (EAE) in mice. Histological evaluation of mouse EAE spinal cords showed that TFA-12 treatment reduces inflammation, astrogliosis, and myelin loss. Additionally, we demonstrated that TFA-12 accelerates remyelination of focal demyelinated lesions induced by lysolecithin injections. We also found that this compound induces the differentiation of oligodendrocyte precursor cells into mature oligodendrocytes through the inhibition of the Notch/Jagged 1 signaling pathway. Altogether, our data provide important proof of principle indicating that TFA-12 could be a potential therapeutic compound for myelin repair in MS.

\section{Introduction}

Multiple sclerosis (MS) is an inflammatory disease of the CNS, leading to chronic demyelination and axonal loss (Compston and Coles, 2008; Trapp and Nave, 2008). MS lesions can be repaired by endogenous oligodendrocyte precursor cells (OPCs) (Fancy et al., 2011). However, in most cases, remyelination fails, resulting in irreversible neurological disability (Chang et al., 2002). Current treatments mainly target the inflammatory component of the disease but have little impact on myelin repair. Therefore, development of therapies promoting remy-

Received Feb. 19, 2013; revised May 13, 2013; accepted June 3, 2013.

Author contributions: B.N.O. designed research; B.B., T.H., C.G., N.M.M., C.C., L.G., A.K., C.K., and M.F. performed research; D.C. contributed unpublished reagents/analytic tools; B.B., T.H., C.G., N.M.M., C.C., L.G., A.K., C.K., A.B.V.E., E.M., P.H., and B.N.O. analyzed data; B.N.O. wrote the paper.

This work was supported by the Institut National de la Santé et de la Recherche Médicale, University of Luxembourg and the Institut Hospitalo-Universitaire de Neurosciences Translationnelles de Paris, A-ICM, Investissements d'Avenir ANR-10-IAIHU-06. B.B. was the recipient of a fellowship from the Luxembourg Ministry of Culture, Higher Education, and Research. C.C. was supported by Inserm and Pierre and Marie Curie University, and N.M.M. was supported by the French Multiple Sclerosis Foundation (ARSEP) and the European Leukodystrophy foundation (ELA). We thank Violetta Zujovic, Aurelia Sahel, Corinne Bachelin, and Cyrille Deboux for helpful comments and critical reading of this manuscript.

The authors declare no competing financial interests.

Correspondence should be addressed to Dr. Brahim Nait Oumesmar, CRICM, Inserm-UPMC, UMRS 975, CNRS UMR 7225, Bâtiment ICM, 47 bd de I'Hôpital, 75651 Paris Cedex 13, France. E-mail: brahim.nait_oumesmar@upmc.fr. DOI:10.1523/JNEUROSCI.0774-13.2013

Copyright $\odot 2013$ the authors $\quad 0270-6474 / 13 / 3311633-10 \$ 15.00 / 0$ elination and neuroprotection would represent an important advance in MS treatment.

Several factors modulating oligodendrocyte differentiation may provide effective pharmacological targets to enhance remyelination in MS. These factors include retinoid X receptor gamma (Huang et al., 2011), Wnt $/ \beta$ catenin (Fancy et al., 2009; Ye et al., 2009), Notch1/Jagged (John et al., 2002; Nakahara et al., 2009; Zhang et al., 2009), and the myelin inhibitor LINGO-1 (Mi et al., 2009). Another strategy to stimulate endogenous myelin repair relies on the delivery of growth factors that regulate survival, proliferation, or differentiation of oligodendroglial cells (Connor and Dragunow, 1998; Decker et al., 2005). However, despite some promising results in experimental models, attempts to develop clinical trials based on growth factors have been mainly unsuccessful (Thoenen and Sendtner, 2002). The major limitations of growth factor-based strategies are caused by their poor penetration into the CNS, low stability, and wide-range activities (Xie and Longo, 2000). Thus, recent efforts have been focused on the development of synthetic molecules, which have the ability to mimic biological effects of neurotrophins with limited side effects.

A number of hybrid molecules that act on regeneration and neuroprotection are derived from $\alpha$-tocopherol, a member of the vitamin $\mathrm{E}$ family that is widely used in clinical practice because of its antioxidant and anti-inflammatory properties (KapelusiakPielok et al., 2005). Moreover, fat-soluble vitamins, including 
<smiles>Cc1c(C)c2c(c(C)c1O)CCC(C)(CO)O2</smiles>

TFA-12
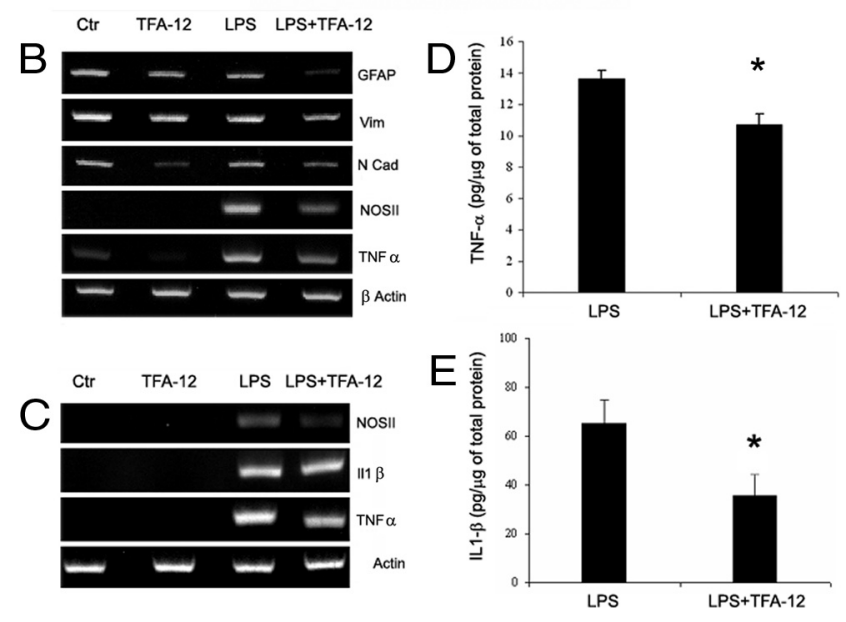

Figure 1. TFA-12 inhibits astroglial and microglial activation in vitro. $\boldsymbol{A}$, Molecular structure of TFA-12. B, RT-PCR analysis of gfap, vimentin, N-cadherin, Nos II, and Inf- $\alpha$ gene expression in astrocyte primary cultures, treated or untreated with TFA- $12\left(10^{-6} \mathrm{M}\right)$ and with or without LPS $(1 \mu \mathrm{g} / \mathrm{ml})$. TFA- 12 inhibits both astrogliosis and inflammatory gene response. C, RT-PCR gene expression analysis in MMGT12 microglial cells. RNA extraction was performed after $6 \mathrm{~h}$ of incubation with TFA-12 $\left(10^{-5} \mathrm{M}\right)$, with or without LPS activation $(0.01 \mu \mathrm{g} / \mathrm{ml})$. Expression of Nosll, II-1 $\beta$, and Tnf- $\alpha$ transcripts in TFA-12-treated MMGT12 cells are significantly decreased. $\beta$-Actin was used as an internal control. D, E, ELISA quantification of TNF $\alpha(\boldsymbol{D})$ and IL1 $\beta$ (E) protein levels in LPS-stimulated MMGT12 microglial cultures treated and untreated with TFA- 12 for $24 \mathrm{~h}$. TFA- 12 inhibits both TNF- $\alpha$ and IL- $1 \beta$ secretion. Data are mean \pm SEM values obtained from three experiments, each conducted in independent cultures $(n=3) .{ }^{*} p<0.01$, Student's $t$ test. Ctr, Control.

$\alpha$-tocopherol, are considered as important disease modulators in MS and show beneficial outcomes on white matter damage in experimental models (Kryzhanovskil et al., 1984; Torkildsen et al., 2013). Among these compounds, the tocopherol long-chain fatty alcohol TFA-12 is a synthetic molecule that combines an $\alpha$-tocopherol moiety and a neurotrophic $\omega$-alkanol side chain with 12 carbon atoms (Muller et al., 2004). TFA-12 is a potent inhibitor of microglial activation in vitro and decreases secretion of nitric oxide and tumor necrosis factor- $\alpha$ (TNF $\alpha$ ) (Muller et al., 2004). Furthermore, TFAs are able to cross the blood-brain barrier when peripherally administrated in a rat model of hippocampal injury (Borg et al., 1990).

In the current study, we analyzed the ability of TFA-12 to improve clinical recovery and repair of demyelinated lesions in two complementary rodent models of MS, the experimental autoimmune encephalomyelitis (EAE) and the lysolecithin (LPC)-induced demyelination. We demonstrated that TFA-12 significantly enhances clinical recovery from EAE, which correlated with reduced inflammation, astrogliosis, and demyelination. Importantly, we showed that TFA-12 accelerates remyelination by promoting OPC differentiation through the inhibition of the Notch signaling pathway.

\section{Materials and Methods}

EAE induction and TFA-12 treatment. All experiments were performed according to European Union regulations and Inserm ethical committee (authorization A-75-1024; 10/26/2012) guidelines. Twelve-week-old
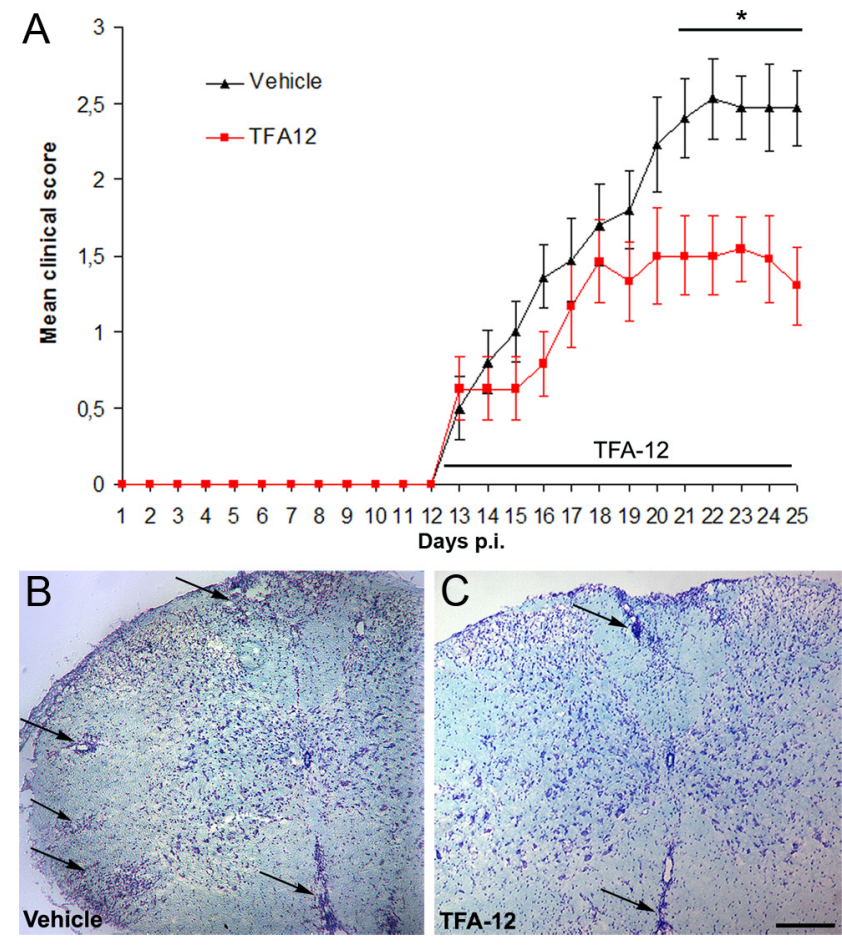

Figure 2. TFA-12 improves the clinical course of MOG-induced EAE. $A$, EAE was induced in C57BL/6 mice by immunization with $\mathrm{MOG}_{35-55}$ peptides, and clinical scores were evaluated daily. TFA-12 $(0.39 \mathrm{mg} / \mathrm{kg})$ or saline solution alone was injected daily from disease onset at 12 dpi. TFA-12 injections improves significantly $\left({ }^{*} p<0.05\right)$ the mean clinical scores in EAE mice compared with vehicle treatment ( $n=20$ for each group) from 20 to 25 dpi. B, C, LFB-cresyl violet staining of spinal cord sections from vehicle-treated ( $\boldsymbol{B}$ ) and TFA-12-treated ( $\boldsymbol{C}$ ) EAE mice at $24 \mathrm{dpi}$. Vehicle-treated mice show large inflammatory foci (arrows) in the spinal cord white matter $(\boldsymbol{B})$, whereas few very cellular infiltrates are detected in spinal cords of TFA-12-treated mice (C). Scale bar, $100 \mu \mathrm{m}$.

C57BL/ 6 female mice ( $n=40$; Janvier) were immunized subcutaneously with an emulsion consisting of $200 \mu \mathrm{g}$ of synthetic myelin oligodendrocyte glycoprotein (MOG) ${ }_{35-55}$ peptides (NeoMPS) in complete Freund's adjuvant (BD Biosciences), supplemented with $500 \mu \mathrm{g}$ of heatinactivated Mycobacterium tuberculosis (strain H37Ra; BD Biosciences). Mice were given intravenous injections of pertussis toxin (List Biological Laboratories) on the day of the immunization and $48 \mathrm{~h}$ later and were divided in two experimental groups. Animals were scored daily for clinical signs ( 0 , healthy; 1 , loss of tail tone; 2 , hindlimb weakness; 3 , hindlimb paralysis; 4 , scale 3 plus forelimb weakness; 5 , death). From day 12 postimmunization ( $12 \mathrm{dpi}$ ) until the end of the experiment, one group $(n=20$ mice $)$ received intraperitoneal injections daily with TFA-12 (0.39 $\mathrm{mg} / \mathrm{kg}$ in $1 \%$ ethanol/saline solution) and the other $(n=20)$ received the vehicle solution only. Animals were killed at $25 \mathrm{dpi}$. TFA-12 synthesis was performed as described previously (Muller et al., 2004), and the dose of TFA-12 used in EAE experiments was based on the optimal concentration eliciting OPC differentiation in vitro (see below). Similar results were reproduced in three independent experiments.

Tissue processing and histological staining. Animals were perfused under deep anesthesia with $4 \%$ paraformaldehyde (PFA) in $0.1 \mathrm{M}$ PBS. Spinal cords were removed, postfixed in the same fixative at $4^{\circ} \mathrm{C}$ for $2 \mathrm{~h}$, and incubated overnight in $15 \%$ sucrose/ $0.1 \mathrm{~m}$ PBS. Tissues were frozen in isopentane $\left(-60^{\circ} \mathrm{C}\right)$, and $12 \mu \mathrm{m}$ coronal sections were performed with a Reichert cryotome (Leica). Sections were stained with Luxol fast blue (LFB; to visualize myelin; Sigma-Aldrich) and Oil Red O (ORO; for macrophages containing myelin debris; Sigma). For LFB staining, sections were dehydrated and incubated in a $0.1 \%$ LFB solution at $37^{\circ} \mathrm{C}$ overnight. Slides were then cooled at $4^{\circ} \mathrm{C}$, incubated in a $0.05 \%$ lithium carbonate solution, and cleared in $70 \%$ ethanol. Slides were next stained with cresyl violet, dehydrated, and mounted in Eukitt (O. Kindler). ORO staining was performed in $0.15 \%$ ORO/36\% triethyl phosphate solution. 

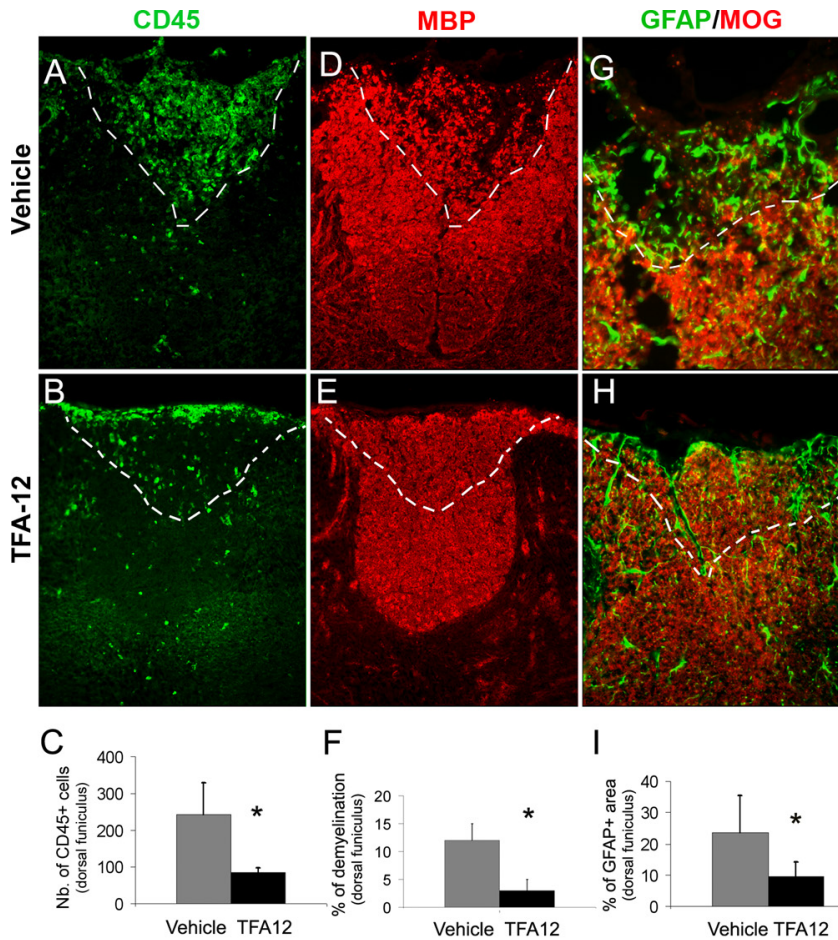

$\mathrm{F}$
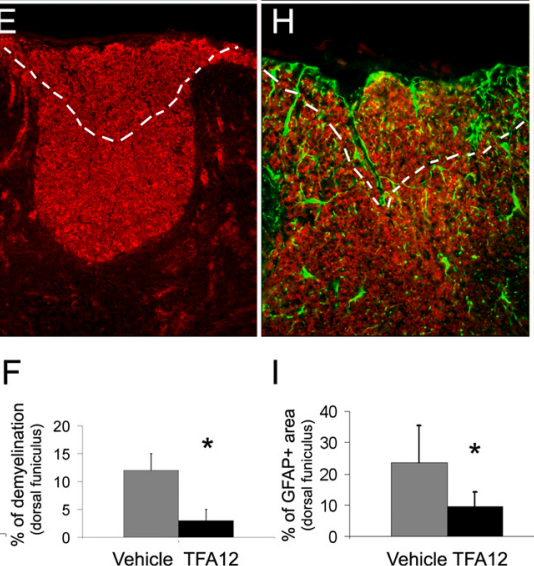

I
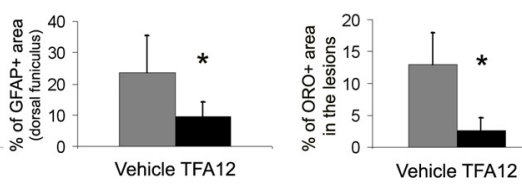

Figure 3. Inflammation, astrogliosis, and demyelination are reduced by TFA-12 treatment. Thoracic spinal cord sections from vehicle-treated $(\boldsymbol{B}, \boldsymbol{E}, \boldsymbol{H}, \boldsymbol{K})$ and TFA-12-treated $(\boldsymbol{A}, \boldsymbol{D}, \boldsymbol{G}, \boldsymbol{J})$ mice were analyzed at $24 \mathrm{dpi} . \boldsymbol{A}, \boldsymbol{B}$, CD45 immunohistochemistry on spinal cord sections of vehicle-treated $(\boldsymbol{A})$ and TFA-12-treated $(\boldsymbol{B})$ EAE mice reveals immune foci (dashed lines) in the dorsal funiculus. $C$, The number of CD45+ cells is decreased by 2.8 -fold in TFA-12-treated mice compared with controls. $\boldsymbol{D}, \boldsymbol{E}$, In vehicle-treated mice, demyelinated lesions are characterized by the lack of MBP staining and myelin debris (D), whereas demyelination is barely visible in TFA-12-treated groups $(\boldsymbol{E})$. $\boldsymbol{F}$, The extent of demyelination is 4.2 -fold lower in TFA-12-treated mice than in controls. G-I, GFAP+ astrogliosis is also drastically reduced by TFA-12 treatment. J-L, ORO staining (red) reveals intense macrophage activity in EAE lesions from vehicle-treated mice $(\boldsymbol{J})$, whereas macrophage activity is significantly reduced under TFA-12 conditions $(\boldsymbol{K}, \boldsymbol{L})$. All quantifications were made on three independent experiments. ${ }^{*} p<0.05$, Student's $t$ test. Scale bar, $50 \mu \mathrm{m}$.

Sections were next rinsed in water, incubated with hematoxylin, and mounted in Fluoromount medium (Clinisciences).

Lysophosphatidylcholine-induced demyelination and ultrastructural analysis of remyelination. Ten-week-old C57BL/6 mice were used to perform focal demyelinated lesions in spinal cords by stereotaxic injections of $1 \%$ lysophosphatidylcholine (LPC; Sigma-Aldrich) in $0.9 \% \mathrm{NaCl}$ solution $(1 \mu \mathrm{l})$ into the dorsal funiculus, as described previously (Nait Oumesmar et al., 1995). After surgery, animals were split into control and experimental groups. TFA-12 compound was administered by daily intraperitoneal injections $(0.39 \mathrm{mg} / \mathrm{kg})$ from day 5 to day 14 . The control group was given injections of vehicle solution only. At $15 \mathrm{~d}$ after LPC injection, lethally anesthetized mice were perfused with $2.5 \%$ glutaraldehyde $/ 2 \%$ PFA in PBS. Spinal cords were dissected, postfixed in $2 \% \mathrm{OsO}_{4}$, and contrasted with 5\% uranyl acetate before embedding in Epon. Ultrathin sections were cut on a vibratome and viewed using a Philips electron microscope. The number of remyelinated axons, identified by their thin myelin sheaths, was quantified on ultrathin sections of the lesions using ImageJ software. Data were expressed as the percentage of total axons within the lesion area. Quantification was performed in a blind fashion by two independent investigators.

Cell cultures. The CG4 cell line was cultured on polyornithine-laminine and expanded in N1/B104 (70/30 v/v) medium, as described previously (Louis et al., 1992). For differentiation assays, N1/B104 was replaced by $\mathrm{N} 1$ containing TFA-12 at $5 \times 10^{-7} \mathrm{M}$ or N1 alone, and the medium was changed daily. TFA-12 concentration of $5 \times 10^{-7} \mathrm{M}$ was selected based on dose-response studies. This concentration elicited an optimal pro-differentiation effect on CG4 cells, whereas TFA-12 concentrations over $10^{-6} \mathrm{M}$ had toxic effects. Primary astrocyte cultures were prepared from newborn Wistar rat pups, as reported previously (Morga et al., 2000). The mouse microglial cell line MMGT12 (gift from Dr. E.
Vanmechelen, Innogenetics, Gent, Belgium) was cultured in DMEM/Ham's F12 (1/1), supplemented with $2 \%$ fetal calf serum (FCS; Invitrogen), $1 \%$ Insulin/Transferrin/Selenium (ITS, Invitrogen) and 15\% filtered conditioned medium of WEHI cells (American Type Culture Collection). This cell line has characteristics of primary microglia (Kieseier et al., 2007). For astrocyte cultures, TFA-12 treatment was performed at $10^{-6} \mathrm{M}$ for $24 \mathrm{~h}$ with or without LPS $(1 \mu \mathrm{g} / \mathrm{ml})$. This concentration was determined in dose-response experiments and elicited a significant response in astrocyte cultures. MMGT12 cultures were treated with TFA-12 at the effective concentration of $10^{-5} \mathrm{M}$ (Muller et al., 2004) with or without LPS stimulation $(0.01 \mu \mathrm{g} / \mathrm{ml})$ for 6 and $24 \mathrm{~h}$ to perform RTPCR and ELISA experiments, respectively.

RT-PCR analysis. Total RNA was purified from astrocyte and microglia cultured cells, as described previously (Grandbarbe et al., 2007). RNA analysis was performed with the RNA electrophoresis Experion system (Bio-Rad) to check their quality and the absence of genomic contamination. One microgram of total RNA was reverse transcribed using the ImProm-II Reverse Transcription System (Promega) with $0.5 \mu \mathrm{g} /$ reaction oligo(dT). For PCR amplification, specific oligonucleotide primer pairs (available upon request) were incubated with 1 $\mu \mathrm{l}$ of cDNA and $0.8 \mathrm{U}$ of TaqDNA polymerase in $25 \mu \mathrm{l}$ of PCR Master Mix (Promega). Typical cycle conditions were $30 \mathrm{~s}$ at $94^{\circ} \mathrm{C}, 30 \mathrm{~s}$ at $55^{\circ} \mathrm{C}$, and $1 \mathrm{~min}$ at $72^{\circ} \mathrm{C}$. Twenty microliters of the resulting mix were then separated on a $2 \%$ agarose gel and visualized by ethidium bromide staining on a transilluminator.

Measurement of TNF- $\alpha$ and IL- $\beta$ productions. TNF and IL- $1 \beta$ concentrations were measured using the DuoSet ELISA/Assay Development kit (R\&D Systems). Intracellular IL- $1 \beta$ was measured by collecting cells in hypotonic buffer. TNF production was measured in the culture supernatant $24 \mathrm{~h}$ after LPS exposure. The protein content of the lysates was determined using Dye Reagent (Bio-Rad) by measuring the absorbance at the wavelength of $595 \mathrm{~nm}$, using bovine serum albumin standards. The data represent mean \pm SEM values from at least three independent experiments.

Differentiation assays in the presence of the Notch agonist Jagged 1. For differentiation experiments of CG4 cells in the presence of Notch agonist Jagged1/Fc, N1/B104 was replaced by N1 supplemented with TFA-12 at $5 \times 10^{-7} \mathrm{M}$ or by N1 alone, with or without the soluble form of the Notch agonist Jagged 1 (recombinant rat Jagged1/Fc chimera; R\&D Systems). The medium was changed daily, and differentiation was performed for $3 \mathrm{~d}$. A dose-response curve of the effects of Jagged 1 on CG4 cells was first established in N1 medium with increasing concentrations of Jagged $1 / \mathrm{Fc}_{\mathrm{c}}$ (ranging from 0 to $8 \mu \mathrm{g} / \mathrm{ml}$ ). The Jagged $1 / \mathrm{Fc}$ concentration of $4 \mu \mathrm{g} / \mathrm{ml}$ was found to inhibit the generation of $\mathrm{O} 4+$ oligodendrocytes by fivefold compared with control cells, after $3 \mathrm{~d}$ in differentiation condition. This concentration was therefore used in these experiments.

Oligodendroglial primary cultures. Primary cultures of oligodendrocytes were performed basically as described by McCarthy and de Vellis (1980). Briefly, cerebral hemispheres were dissected from newborn transgenic EGFP rats (Okabe et al., 1997), freed of meninges, and dissociated by gentle repetitive pipetting in a mixture of DMEM/F-12 (1:1) containing $1 \%$ streptomycin/penicillin supplemented with $10 \%$ fetal calf serum. The cell suspension was seeded in poly-L-lysine-coated flasks. After $14 \mathrm{~d}$ in culture, microglia was separated by shaking for $45 \mathrm{~min}$ in an orbital shaker at $250 \mathrm{rpm} / \mathrm{min}$, and oligodendrocytes were separated 
from the astrocytes by continuous shaking overnight at $300 \mathrm{rpm} / \mathrm{min}$. The cell suspension was filtered and centrifuged at $1000 \mathrm{rpm}$ for $5 \mathrm{~min}$. The pellet containing the oligodendrocytes was resuspended in $\mathrm{N}$ medium containing a 1:1 mixture of DMEM/F-12, $0.6 \%$ glucose, $25 \mu \mathrm{g} / \mathrm{ml}$ insulin, $1 \% \mathrm{~N} 2 \mathrm{mix}, 0.5 \% \mathrm{~B} 27$, and $0.5 \%$ HEPES and was plated in poly-L-lysine 24 -well plates $\left(5 \times 10^{4}\right.$ cells/well). The cell cultures were kept for $2 \mathrm{~d}$ in $\mathrm{N}$ medium in the absence or presence of $5 \times 10^{-7} \mathrm{M}$ TFA-12. The medium was changed every day. Cells were fixed in $4 \%$ PFA and used for morphological and immunocytochemical analyses.

Immunochemistry. Sections were incubated overnight with primary antisera at $4^{\circ} \mathrm{C}$, rinsed, and incubated with the appropriate secondary antibodies for $1 \mathrm{~h}$ at $20^{\circ} \mathrm{C}$. They were next counterstained with bisbenzimide (Hoescht 33342; Sigma-Aldrich), washed, and mounted with Fluoromount (Clinisciences). For in vivo experiments, the following antibodies were used: rabbit anti-MBP (1:100; Millipore) and mouse anti-MOG (1:20, 8-18C5 hybridoma; gift from C. Linington, University of Aberdeen, Aberdeen, UK) for myelin staining; rat antiCD45 (1:100; Invitrogen) for immune cells; rabbit anti-NG2 (1:100; Abcys) for OPCs; and mouse anti-APC7 (1:100, clone CC1; Calbiochem) for postmitotic oligodendrocytes. For in vitro experiments, cells were incubated with O4 (1:1; American Type Culture Collection) or GalC (1:1; Millipore) primary antibodies for $30 \mathrm{~min}$ at $20^{\circ} \mathrm{C}$. For Ki67 staining (1:100; BD Biosciences), cells were fixed with ice-cold $2 \%$ PFA, rinsed twice with PBS, and incubated with the primary antibody. Cells were incubated with secondary antibodies for $30 \mathrm{~min}$, rinsed in PBS, counterstained with Hoescht 33342, and mounted with fluoromount (Clinisciences). Slides and cells were analyzed under a DMRA fluorescence microscope (Leica).

Quantification. In vitro, cell counts were established on three separates experiments. Quantifications are mean \pm SEM values of the data collected from at least six coverslips for each experiment. To avoid subjective selection, microscopic fields were randomly selected, and at least 500 cells were counted for each coverslip. For EAE experiments, cell counts were performed in CD45+ EAE lesions with at least six animals per group. For each animal, staining and cell counts were made on $15 \mathrm{sec}-$ tions from at least three distinct slides covering all spinal cord levels. To limit experimental bias, immunolabelings were performed at the same time and images were taken with the same acquisition parameters. For each marker, counts were performed in EAE lesions defined by MBP and CD45 coimmunolabeling on adjacent sections. Measurements were performed in CD45 + foci and processed with ImageJ 1.34S. For NG2 staining, positive cells with DAPI+ nuclei were quantified and separated from each other using high-resolution fluorescence microscopy as reported previously (Reynolds et al., 2002; Dawson et al., 2003).

Real-time PCR. Total RNAs were isolated using Trizol reagent (Invitrogen). DNA contamination was removed with DNaseI treatment, and 1 $\mu \mathrm{g}$ of RNA was synthesized into first-strand cDNA using the Thermoscript RT-PCR System kit (Invitrogen). Three replicates of real-time PCR experiments were performed using an ABIprism 7000 sequence detection system with Taqman gene expression assay probes (Applied Biosystems). After real-time PCR experiments, the Ct number was extracted for both the reference gene $(G A P D H)$ and the target gene with automatic baseline and manual threshold. We used the $\Delta \Delta \mathrm{Ct}$ model to determine fold increases and the Wilcoxon test on $\Delta \mathrm{Ct}$ for statistical analysis. Data are mean \pm SEM of at least three separate experiments.

Statistical analysis. The Student's $t$ test and Mann-Whitney $U$ test were used to assess statistical significance (SigmaStat 3.1; Systat Software). The $p$ values $<0.05$ were considered significant.

\section{Results}

TFA-12 inhibits astroglial and microglial activation in vitro As a first attempt to define the biological activity of TFA-12 (Fig. $1 A$ ), we tested whether this molecule modulates astroglial and microglial activation induced by LPS treatment in vitro (1 and $0.01 \mu \mathrm{g} / \mathrm{ml}$ for astroglial and microglial cultures, respectively). In primary astrocyte cultures, RT-PCR experiments for Gfap, $\mathrm{Vi}$ mentin, and $\mathrm{N}$-Cadherin revealed that TFA-12 reduced the expression of astroglial genes, even in response to LPS activation
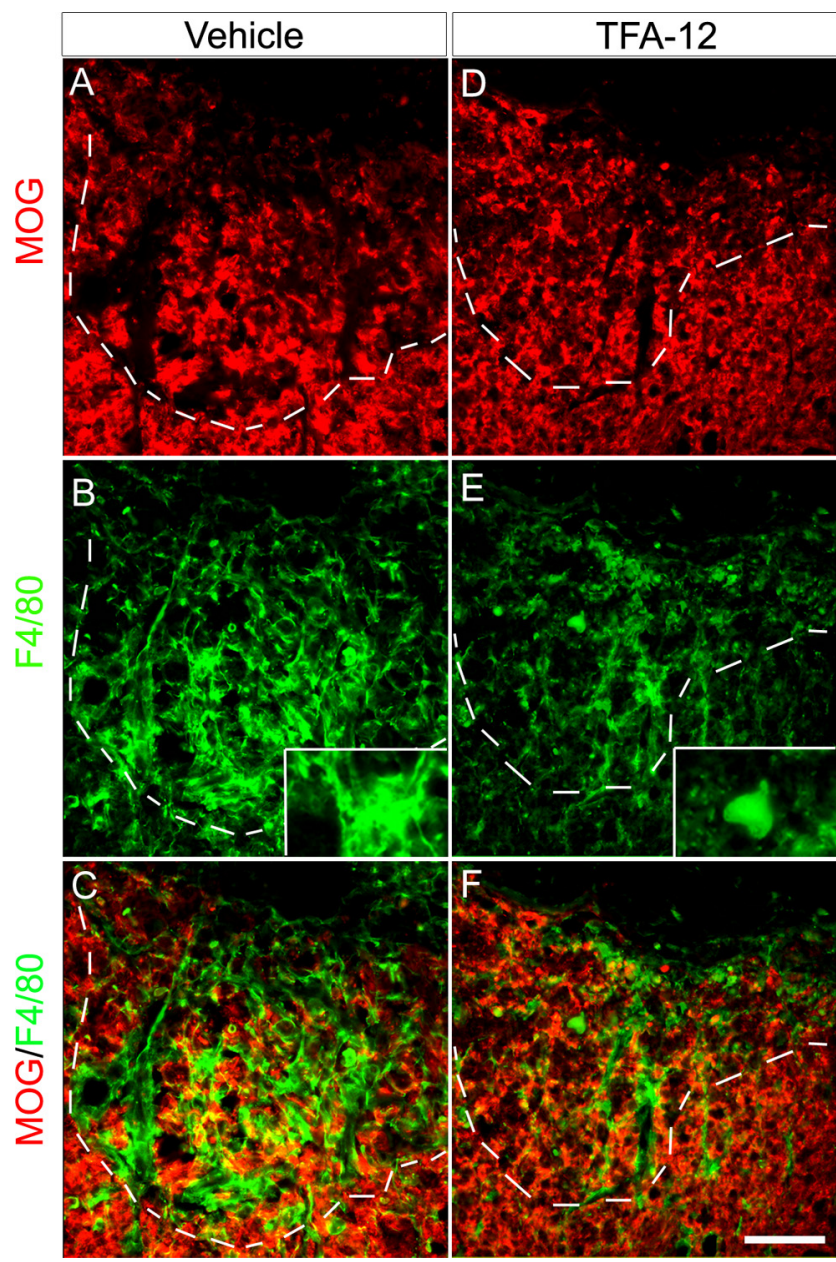

Figure 4. TFA-12 treatment reduced microglial activation in MOG-induced EAE. Coronal spinal cord sections from vehicle-treated $(\boldsymbol{A}, \boldsymbol{B})$ and TFA-12-treated $(\boldsymbol{D}-\boldsymbol{F})$ EAE mice stained for MOG $(\boldsymbol{A}, \boldsymbol{D})$ and F4/80 $(\boldsymbol{B}, \boldsymbol{E})$ at 24 dpi. EAE lesions are delimited by dashed lines. $\boldsymbol{A}, \boldsymbol{B}, \boldsymbol{D}, \boldsymbol{E}, \mathrm{In}$ vehicle-treated spinal cords, lesions lacking MOG labeling $(\boldsymbol{A})$ were filled with numerous activated $\mathrm{F} 4 / 80+$ microglia $(\boldsymbol{B})$, whereas in TFA-12-treated mice $(\boldsymbol{D}), \mathrm{F} 4 / 80+$ microglial cells are strongly reduced $(\boldsymbol{E}) . \boldsymbol{C}, \boldsymbol{F}$, Merge fields are shown. Scale bar, $50 \mu \mathrm{m}$.

(Fig. $1 B$ ). NosII and Tnf $\alpha$ gene expression were also significantly downregulated in astrocyte cultures treated with TFA-12. We also noticed that LPS treatment alone slightly reduced the expression of astroglial transcripts, as reported previously (Selmaj et al., 1991; Murphy et al., 1995). Similar experiments were also performed on the primary microglial cell line (MMGT12 cells) induced to produce $T n f-\alpha, I l-1 \beta$, and NosII in response to LPS stimulation for $24 \mathrm{~h}$. The addition of TFA-12 to LPS-treated cultures effectively inhibited the expression of major mediators of microglial activation such as Tnf- $\alpha$ and NosII (Fig. 1C). This inhibition was also confirmed by ELISA analysis of TNF- $\alpha$ (Fig. $1 D$ ) and IL-1 $\beta$ (Fig. 1E) protein levels in TFA-12-treated MMGT12 culture supernatants. These data demonstrate that TFA-12 is an effective inhibitor of astroglial and microglial activation and, therefore, may prevent inflammatory insults in the CNS.

\section{TFA-12 enhances clinical recovery of MOG-induced EAE disease}

Having established that TFA-12 had anti-inflammatory properties in vitro, we next tested whether this compound had a beneficial effect on the clinical course of MOG-induced EAE in mice. 

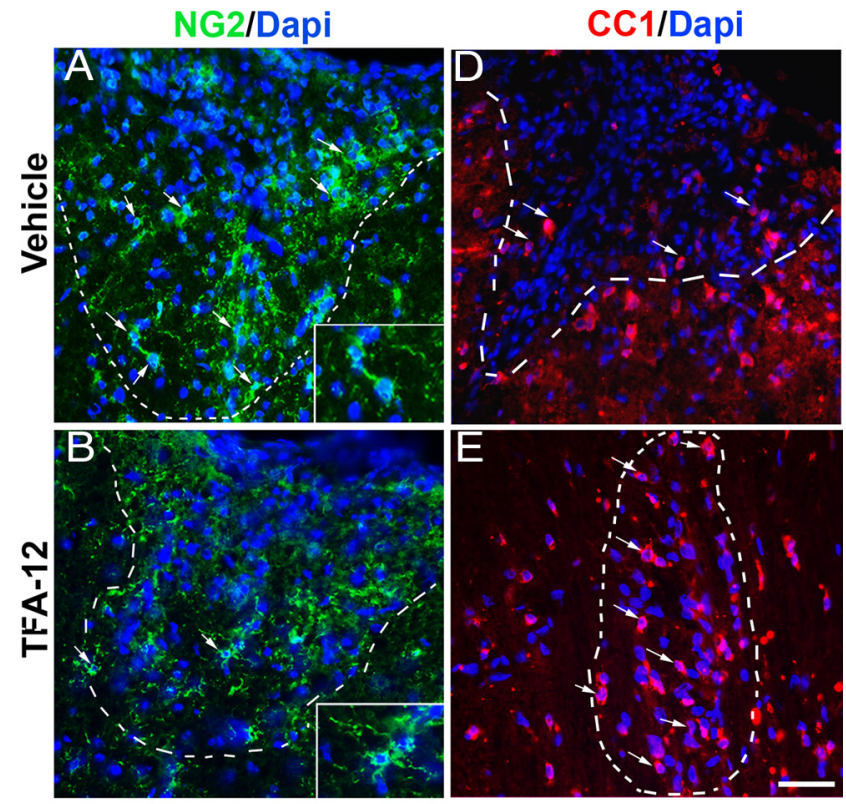

C

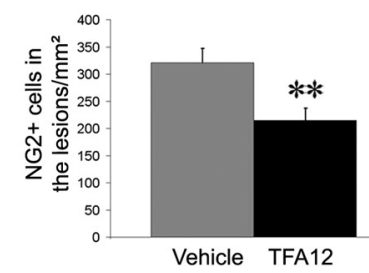

F

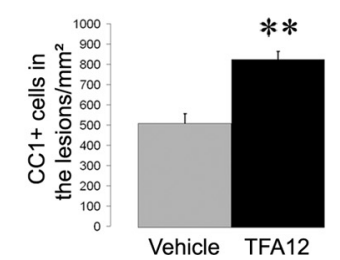

Figure 5. TFA-12 impacts on oligodendroglial cells in EAE lesions. $\boldsymbol{A}, \boldsymbol{B}$, Immunolabeling for $N G 2+O P C s$ in EAE lesions of vehicle-treated $(\boldsymbol{A})$ and TFA12-treated $(\boldsymbol{B})$ mouse spinal cords. $\boldsymbol{C}$, Cell counts in EAE lesions reveal a significant reduction in the number of NG2 + cells (arrows), under TFA-12 conditions. $\boldsymbol{D}, \boldsymbol{E}, \mathrm{CC} 1$ immunolabeling (arrows) in spinal cord EAE lesions from vehicle- and TFA-12-treated mice. $\boldsymbol{F}$, Quantification of CC1 + cells shows a 1.6-fold increase of the number $\mathrm{CC} 1+$ oligodendrocytes in TFA-12-treated groups. The dashed lines outline the border of EAE, as defined by CD45 immunolabeling on adjacent sections. ${ }^{* *} p<0.01$, Student's $t$ test. Scale bar, $50 \mu \mathrm{m}$.

This EAE model mimics important pathological hallmarks of MS lesions, with inflammatory lesions occurring mainly in the spinal cord and resulting in chronic demyelination (Hobom et al., 2004). Moreover, in this well characterized MOG-EAE model, the onset of clinical symptoms (score of $0.5-1$ ) is strongly correlated with the occurrence of inflammatory white matter lesions, which extend with disease progression (Jones et al., 2008; Recks et al., 2011). Thus, this model is suitable for evaluating the therapeutic potential of TFA-12 in MS. EAE-induced mice were given daily injections of TFA-12 $(0.39 \mathrm{mg} / \mathrm{kg}, n=20)$ or the vehicle alone (saline solution with $0.2 \%$ alcohol, $n=20$ ) from the onset of clinical signs at $12 \mathrm{dpi}$ until $25 \mathrm{dpi}$. Mice treated with the vehicle alone showed typical EAE disease course, with clinical scores increasing progressively from 12 to $21 \mathrm{dpi}$ and reaching 2.5 (Fig. 2A). In contrast, TFA-12-treated mice displayed a significant reduction of the mean clinical score, which was never $>1.5$. To validate the clinical improvement induced by TFA-12, we stained spinal cord sections from EAE mice with cresyl violet for cellular infiltrates. This staining revealed numerous inflammatory foci in the white matter of vehicle-treated mouse spinal cords (Fig. 2B), whereas TFA-12-treated mice showed much lower cellular infiltrations (Fig. 2C).
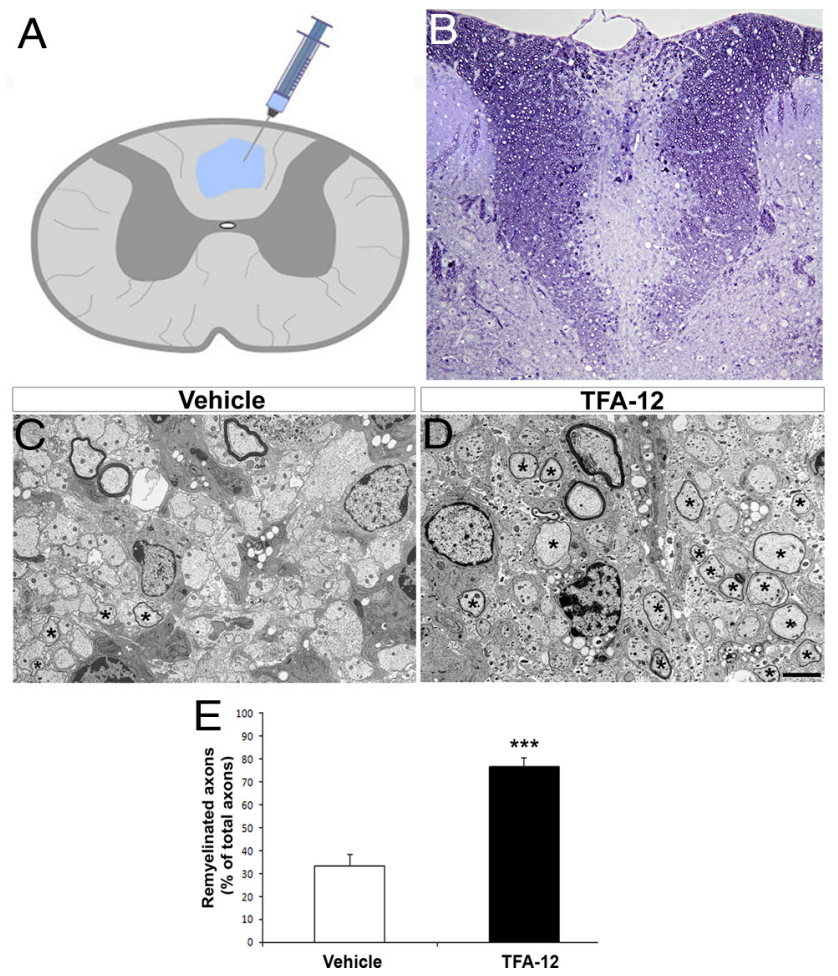

Figure 6. TFA-12 treatment enhances amount of remyelinated axons in LPC-induced lesions. $\boldsymbol{A}$, Schematic representation of LPC-induced demyelination in the mouse spinal cord dorsal funiculus. $\boldsymbol{B}$, Toluidine blue semithin section illustrating $L P C$-induced demyelination at 2 dpi. $\boldsymbol{C}, \boldsymbol{D}$, Ultrathin micrographs of the lesions in vehicle-treated $(\boldsymbol{C})$ and TFA-12-treated (D) mice at $15 \mathrm{dpi}$. TFA-12 treatment enhances the number of remyelinated axons, identified by their thin myelin sheaths ( $\boldsymbol{D}$, asterisks), whereas vehicle-treated mice had significantly fewer remyelinated axons (C).E, Quantification of remyelinated axons over the total number of axons within the lesion shows a significant increase under TFA-12 treatment. ${ }^{* * *} p<0.001$, Student's $t$ test. Scale bars: $\boldsymbol{B}, 100 \mu \mathrm{m} ; \boldsymbol{C}, \boldsymbol{D}, 5 \mu \mathrm{m}$.

\section{TFA-12 reduces inflammation, astrogliosis, and} demyelination in EAE

To further confirm the anti-inflammatory properties of TFA-12, we stained spinal cord sections from EAE mice at 25 dpi with CD45 and MBP to identify leukocytes and demyelinated lesions. In TFA-12-treated mice, CD45 staining revealed very few leukocyte infiltrates often disseminated in the spinal cord white matter tracts (Fig. $3 B$ ), whereas in EAE mice treated with the vehicle alone, numerous CD45+ cells were detected in lesioned areas (Fig. 3A). We quantified the number of CD45+ cells in dorsal funiculus at the thoracic level in both groups and demonstrated that the number of leukocytes was decreased by 2.8-fold in TFA12-injected EAE mice compared with controls (Fig. 3C). Furthermore, microglial activation assessed by F4/80 immunolabeling was also strongly attenuated in the TFA-12-treated group (Fig. $4 A-C$ ) compared with vehicle-treated EAE mice (Fig. $4 D-F$ ). These results indicate that TFA-12 acts a potent inhibitor of CNS inflammation. We next analyzed the extent of demyelination in CD45 + EAE lesions in both experimental groups using MBP immunohistochemistry (Fig. 3D,E). Vehicle-treated mice showed large demyelinated lesions filled with $\mathrm{MBP}+$ myelin debris (Fig. $3 D$ ), whereas TFA-12-treated mice exhibited much smaller demyelinated areas in similar thoracic levels (Fig. 3E). Quantification of MBP-negative areas revealed a significant reduction of demyelination in the TFA-12 treatment group (Fig. $3 F$ ). We next examined the effects of TFA-12 on astrogliosis in EAE spinal cord sections using immunolabeling for GFAP. Quantification of 
GFAP immunoreactivity revealed a 2.4fold reduction of reactive astrogliosis after TFA-12 administration (Fig. 3G-I). To assess the effects of TFA-12 treatment on active demyelination, we also used ORO staining that specifically labels myelin debris in macrophages. In vehicle-treated spinal cords, lesions showed intense ORO staining, indicating that active demyelination was still occurring (Fig. $3 J$ ). In contrast, spinal cord lesions from TFA-12treated mice were rarely labeled with ORO (Fig. $3 K$ ). Quantification of ORO labeling revealed a significant decrease under TFA-12 conditions (Fig. 3L), confirming that active demyelination was prevented by this compound.

We also analyzed the effects of TFA-12 on oligodendroglial lineage cells, using NG2 and CC1 immunohistochemistry. Our results indicated that TFA-12 treatment reduced significantly the density of $\mathrm{NG} 2+$ OPCs (Fig. 5A-C) at the expense of $\mathrm{CC} 1+$ differentiated oligodendrocytes in EAE lesions (Fig. 5D-F). In contrast, the density of NG2+ OPCs was 1.5-fold higher in vehicle groups, and the number of $\mathrm{CC} 1+$ cells decreased in similar range (Fig. 5C,F), suggesting that this compound induces oligodendrocyte differentiation. Overall, these results indicate that TFA-12 lead to histological improvement of inflammation, astrogliosis, and demyelination and further suggest that this compound may enhance the differentiation of endogenous OPCs into remyelinating oligodendrocytes.

\section{TFA-12 promotes remyelination of} focal demyelinated lesions

To test whether TFA-12 could promote remyelination, we used the LPC-induced demyelination model of the mouse spinal cord (Fig. 6A,B). Compared with MOG-induced EAE, demyelination and remyelination are temporally distinct with demyelination occurring at $1 \mathrm{dpi}$ after LPC treatment, followed by a proliferation/recruitment phase of the endogenous OPCs, a differentiation phase beginning at $7 \mathrm{dpi}$, and a remyelination process starting around $14 \mathrm{dpi}$ and almost complete at $30 \mathrm{dpi}$. Therefore, this model provides a significant time frame for quantitative analysis of the remyelination process after TFA-12 treatment. Two groups of mice were analyzed: a control group that received injections of the vehicle solution alone $(n=6)$ and an experimental group of mice that received intraperitoneal injections of TFA-12 $(n=6)$. TFA-12 treatment was initiated at $5 \mathrm{dpi}$, when local inflammation is fading away and OPC differentiation onsets, and further continued daily for $10 \mathrm{~d}$. Ultrastructural analysis of remyelinated versus demyelinated axons was performed on ultrathin sections through the lesions at $15 \mathrm{dpi}$. We found that the percentage of remyelinated axons identified by thin myelin sheaths, over the total number of axons, was significantly increased in LPC lesions from mice treated with TFA-12 (Fig. 6D,E) compared with controls (Fig. $6 C, E)(76.8 \pm 3.6 \%$ in TFA12 vs $33.5 \pm 4.8 \%$ in controls). As expected in the LPC model of demyelination, we found that axonal density remained unchanged in both experimental groups (vehicle, $49.9 \pm 8.4 \times 10^{3}$ vs TFA12: $50.5 \pm 3.1 \times 10^{3}$ axons $/ \mathrm{mm}^{2}$ ). These data clearly demonstrate that TFA-12, in addition to its anti-inflammatory properties, promotes remyelination by endogenous OPCs.

\section{TFA-12 promotes oligodendrocyte differentiation in vitro}

To further examine whether the remyelinating activity of TFA-12 is related to a direct effect on OPCs, we analyzed the properties of this compound in CG4 (Louis et al., 1992) and primary OPC cultures. CG4 cells were maintained as immature A2B5+/ O4- OPCs in N1 medium supplemented with B104 conditioned medium and induced to differentiate in N1 medium without serum for $5 \mathrm{~d}$. We assessed the effects of TFA-12 $\left(5 \times 10^{-7} \mathrm{M}\right)$ on CG4 cells in differentiation medium, using immunocytochemistry for A2B5 for OPCs, O4 which labels pre-oligodendrocytes and $\mathrm{GalC}$ for differentiated oligodendrocytes. Under differentiation conditions, TFA-12 treatment for $48 \mathrm{~h}$ increased by 2.5 -fold the 

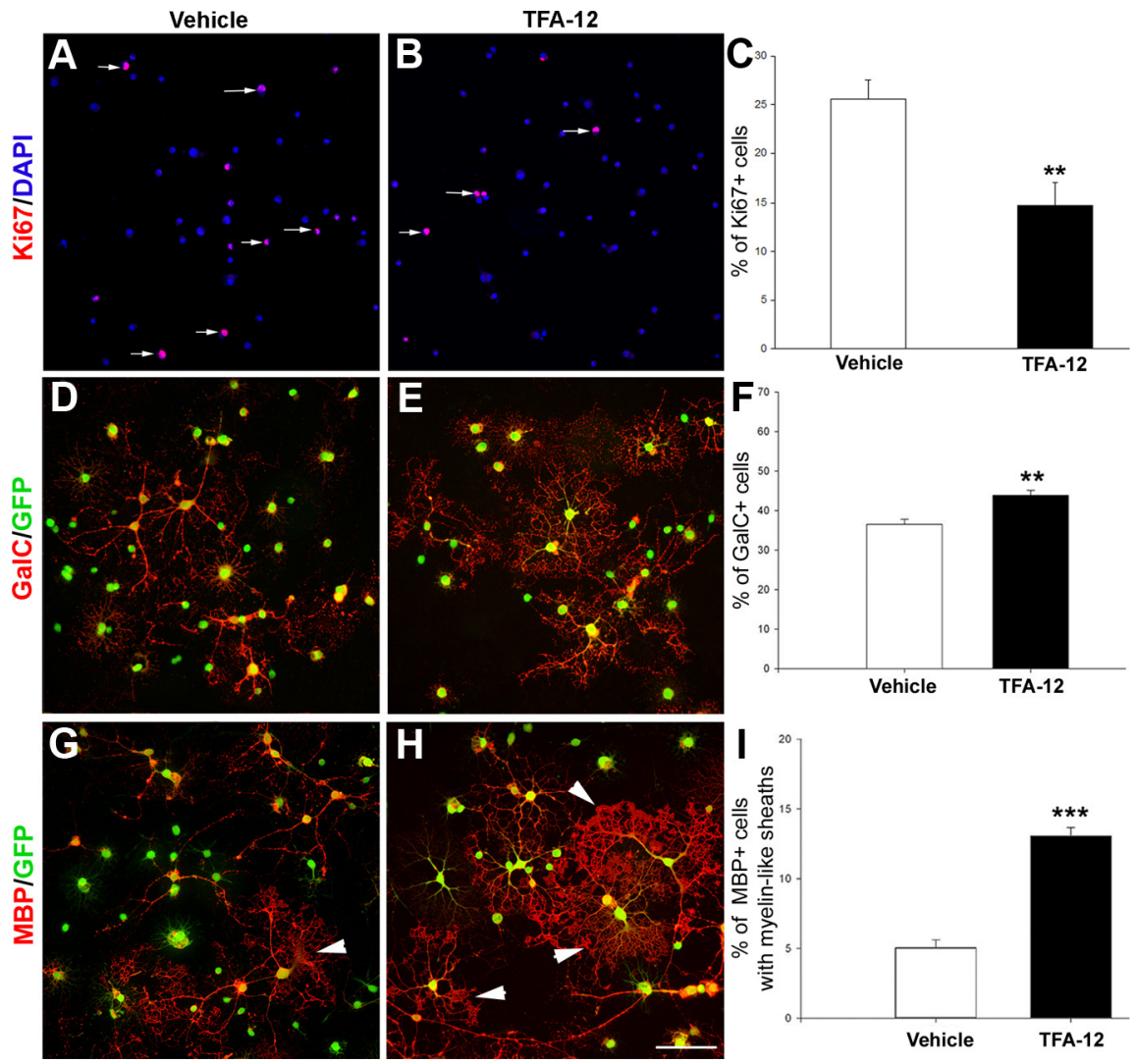

Figure 8. TFA-12 enhances oligodendrocyte differentiation in primary OPC cultures. Primary OPCS, prepared from CAG-GFP transgenic newborn rat brains, were cultured $5 \mathrm{~d}$ in $\mathrm{N}$ medium alone or in $\mathrm{N}+5 \times 10^{-7} \mathrm{M}$ TFA-12. $\boldsymbol{A}, \boldsymbol{B}$, Ki67 immunocytochemistry in vehicle-treated $(\boldsymbol{A})$ and TFA-12 treated $(\boldsymbol{B})$ cultures. $\boldsymbol{C}$, The number of Ki67 + cells is significantly reduced in TFA-12-treated cultures. $\boldsymbol{D}-\boldsymbol{F}$, GalC and GFP coimmunostaining in vehicle-treated $(\boldsymbol{D})$ and TFA-12-treated $(\boldsymbol{E})$ OPC cultures. Cells counts confirm the significant increase in the number of GalC + differentiated oligodendrocytes with complex processes $(\boldsymbol{D}-\boldsymbol{F}) . \mathbf{G}, \boldsymbol{H}, \mathrm{MBP}$ and GFP coimmunolabeling in control $(\boldsymbol{G})$ and TFA-12-treated $(\boldsymbol{H})$ cultures reveals a significant increase of MBP + mature oligodendrocytes bearing myelin-like sheaths $(\boldsymbol{G}, \boldsymbol{H}$, arrowheads; $\boldsymbol{I}) .^{* *} p \leq 0.01 ;{ }^{* * *} p \leq 0.001$, Student's $t$ test. Scale bar, $100 \mu \mathrm{m}$.

number of $\mathrm{O} 4+$ oligodendrocytes compared with control cultures (Fig. 7A-C). The degree of differentiation of CG4 cells was also evaluated by counting the total number of $\mathrm{O} 4+$ oligodendrocytes with zero to two, three to four, and more than four processes emerging from the cell body. Under TFA-12 treatment, CG4 cells were significantly more branched compared with vehicletreated cells (Fig. 7D-F). Furthermore, the differentiation activity of TFA-12 was confirmed by the significant increased number of GalC + differentiated oligodendrocytes $(19 \pm 0.17 \%$ of GalC + cells in TFA-12 medium vs $14 \pm 0.14 \%$ in N1 medium alone; Fig. $7 J-L$ ). As differentiation is often correlated with cell-cycle exit, we noticed that the number of Ki67+ cells was drastically reduced by 11 -fold under TFA-12 conditions (Fig. 7G-I).

Similar experiments were next performed with primary OPC cultures purified from newborn transgenic rat pups expressing GFP under the control the ubiquitous $\beta$-actin promoter (Okabe et al., 1997). This reporter line allowed us to follow morphological changes associated with cell differentiation based on GFP fluorescence. To test the effect of this compound on primary OPC differentiation, we examined cell proliferation using Ki67 labeling after $2 \mathrm{~d}$ in $\mathrm{N}$ medium plus TFA-12 $\left(5 \times 10^{-7} \mathrm{M}\right)$ or in $\mathrm{N}$ medium plus vehicle. Interestingly, the number of Ki67+ cells was significantly reduced under TFA-12 conditions compared with controls (Fig. 8A-C). Furthermore, the number of GalC+/ $\mathrm{GFP}+$ differentiated oligodendrocytes significantly increased under TFA-12 conditions, and GalC-expressing cells exhibited a ramified morphology with complex processes (Fig. 8D-F). Importantly, the prodifferentiation activity of TFA-12 was confirmed by the significant increase of $\mathrm{MBP}+$ oligodendrocytes with myelin-like sheaths under TFA-12 conditions (Fig. $8 G-I)$. Altogether, our results indicate that TFA-12 acts as a potent promyelinating compound by inducing OPC differentiation.

\section{TFA-12 acts as an antagonist of the} Notch signaling pathway

To get a better insight into the mechanisms by which TFA-12 triggers oligodendrocyte differentiation, we next tested whether this compound could modulate the Notch signaling pathway. Notch plays a crucial role in oligodendrocyte development, and activation of Notch receptors was shown to maintain OPCs at an immature stage and to inhibit their differentiation (Park et al., 2005; Yoon and Gaiano, 2005). Moreover, Notch activation induces the expression of the downstream effectors Hes1 and Hes5, which downregulate expression of bHLH transcription factors such as Mash1. Interestingly, both Hes 1 and Hes5 gene expression, assessed by real-time PCR, were decreased by fourfold in CG4 cultures treated with TFA-12 concentrations of $10^{-8}$ and $10^{-6}$ M (Fig. 9A). Inhibition of Hes genes in TFA-12-treated cultures $\left(10^{-6} \mathrm{M}\right)$ was further correlated with a fourfold increase of Mash1 transcripts, a bHLH factor involved in oligodendrocyte specification and differentiation (Parras et al., 2007; Sugimori et al., 2007).

To further validate TFA-12 as an antagonist of the Notch pathway, CG4 differentiation was performed for $3 \mathrm{~d}$ in N1 medium alone, $\mathrm{N} 1$ supplemented with Jagged1/Fc $(4 \mu \mathrm{g} / \mathrm{ml})$, or N1 medium containing Jagged $1 / \mathrm{Fc}(4 \mu \mathrm{g} / \mathrm{ml})$ and TFA-12 $\left(5 \times 10^{-7}\right.$ M). Cell counts showed a significant decrease of $\mathrm{O} 4+$ oligodendrocytes in $\mathrm{N} 1+$ Jagged/Fc medium compared with $\mathrm{N} 1$ alone, indicating that Jagged activation of the Notch signaling pathway in OPCs prevented their differentiation, as described previously (Wang et al., 1998; Genoud et al., 2002). Interestingly, Jagged1mediated inhibition of OPC differentiation was significantly reversed by TFA-12 (20 $\pm 0.033 \%$ of $\mathrm{O} 4+$ cells in $\mathrm{N} 1+$ Jagged $1 / \mathrm{Fc}$ vs $30 \pm 0.031 \%$ in $\mathrm{N} 1+$ Jagged $1 / \mathrm{Fc}+\mathrm{TFA}-12$ ) (Fig. $9 B$ ), demonstrating that this compound acts as potent inhibitor of the Jagged/ Notch signaling pathway. Altogether, our results provide compelling evidence indicating that TFA-12 induces oligodendrocyte differentiation through the inhibition of the Notch pathway.

\section{Discussion}

In the present study, we showed that the tocopherol derivative TFA-12 reduces the severity and improves clinical recovery of EAE in mice. These effects were correlated with the reduction of several deleterious parameters of the EAE pathological process, including inflammation, astrogliosis, and demyelination. We also found that TFA-12 accelerates remyelination of focal demyelinated 
lesions induced by LPC injection. Moreover, we demonstrated that TFA-12 enhances OPC differentiation into myelinating oligodendrocytes through the inhibition of the Notch signaling pathway.

The anti-inflammatory properties of TFA- 12 in astroglial and microglial cultures lead us to test the therapeutic relevance of this compound in mouse EAE, a common model of MS. We tested the outcome of intraperitoneal injections of TFA-12 in MOGinduced EAE and found that this molecule at a dose of $0.39 \mathrm{mg} / \mathrm{kg}$ attenuated significantly the severity of the disease compared with vehicle-injected groups. Histological analyses of EAE lesions revealed that TFA-12 leads to a significant reduction of neuroinflammation. These anti-inflammatory properties may explain the beneficial properties of this hybrid molecule on several detrimental components of EAE, including demyelination and astrogliosis. In our study, TFA-12 treatment was initiated at onset clinical symptoms and thus when white matter lesions had already started. Since inflammation is beneficial for remyelination (Kotter et al., 2001; Setzu et al., 2006; Hohlfeld et al., 2007), TFA-12 treatment before disease onset may prevent inflammation and, subsequently, OPC recruitment and remyelination. However, for the prospective design of effective therapies, various administration routes would need to be tested in mouse models of demyelination to optimize doses, duration, and longterm effects of TFA- 12 .

We also demonstrate that astrogliosis was attenuated in EAE lesions of TFA-12-treated mice. This finding was also supported by our in vitro data indicating that LPS-activated astrogliosis was inhibited by TFA-12, as evidenced by reduced levels of NosII, gfap, vimentin, and $N$-cadherin gene expression. Although reactive astrogliosis creates a permissive environment for remyelination (Williams et al., 2007; Nash et al., 2011), it also contributes to the formation of the glial scar expressing several inhibitory molecules preventing OPC migration and differentiation (Back et al., 2005; Franklin and Ffrench-Constant, 2008;), as well as axonal regeneration (Ridet et al., 1997). By preventing the formation of the glial scar, TFA-12 may thus contribute to the overall reduction of demyelination in MOG-induced EAE.

Our data clearly demonstrated that TFA-12 accelerates remyelination of focal demyelinated lesions induced by LPC injections, a model where lesions are not primarily mediated by immune attacks. This suggests that this molecule acts directly on oligodendroglial cells. To unambiguously assess the activity of this compound on oligodendroglial cells, we examined its potential effects in vitro and found that TFA-12 promoted the differentiation of OPC into mature oligodendrocytes. Although we cannot rule out indirect mechanisms through other cells types, we provide compelling evidence indicating that TFA-12 mediated oligodendrocyte differentiation, likely by inhibition of Notch signaling. First, TFA-12 repressed the expression of Notch downstream effectors Hes1 and Hes5 and concomitantly upregulated Mash1, a bHLH transcription factor involved in oligodendrocyte differentiation (Parras et al., 2007). Second, TFA-12 was able to reverse the inhibition of OPC differentiation triggered by the Notch agonist Jagged1. The precise mechanism of this antagonistic effect may be linked to direct binding of TFA-12 to Notch receptors or downstream in the signaling pathway by inhibition of $\gamma$-secretase activity or as a result of the inhibition of the nuclear translocation of Notch intracellular domain NICD (Yoon and Gaiano, 2005). Similarly to TFA-12, it has been reported that administration of $\gamma$-secretase inhibitors to EAE mice improves clinical recovery correlating with reduced astrogliosis and enhanced remyelination (Jurynczyk et al., 2005). During developmental myelination, the Notch signaling pathway
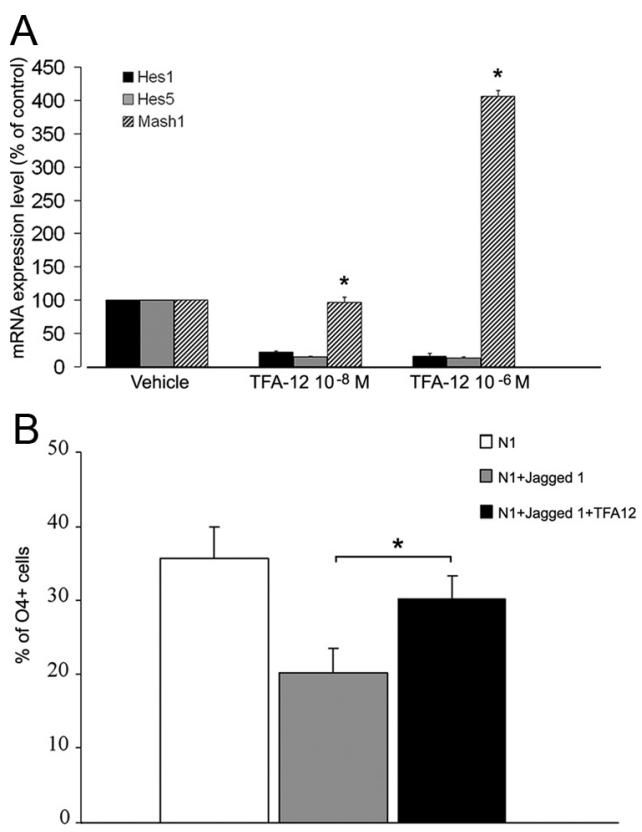

Figure 9. TFA-12 acts as an antagonist of the Notch signaling pathway. $\boldsymbol{A}$, Real-time RT-PCR of Hes 1, Hes5, and Mash1 gene expression levels in CG4 cells untreated and treated with TFA-12 for $48 \mathrm{~h}$. The expression of Notch downstream effectors Hes 1 and Hes 5 is reduced by fourfold under TFA-12 treatment, whereas Mash1 expression is increased by fourfold, indicating that this compound acts as potent inhibitor of Notch signaling. The Wilcoxon test performed on $\Delta \mathrm{Ct}$ was used to confirm significance between TFA-12 and control groups $\left({ }^{*} p<0.05\right)$. B, Quantification of $04+$ cells after $3 \mathrm{~d}$ of differentiation in N1, N1+Jagged1/Fc, and N1+Jagged1/ Fc + TFA-12. As expected, Jagged-mediated Notch activation prevents CG4 cell differentiation into $04+$ oligodendrocytes. This effect was significantly reversed by TFA-12 at $5 \times 10^{-7} \mathrm{M}$. ${ }^{*} p<0.05$ for N1+ Jagged1/Fc versus N1+Jagged1/Fc + TFA-12, Student's $t$ test. Data are mean \pm SEM of three independent experiments.

plays a critical role in oligodendrocyte proliferation and acts as a negative regulator of OPC differentiation (Wang et al., 1998; John et al., 2002; Hu et al., 2003; Zhang et al., 2009). The first downstream effectors of this signaling pathway, Hes1 and Hes5, are part of the bHLH family of transcription factors, homologous to the Drosophila hairy and enhancer split that represses expression of pro-neural genes, such as Mash1 and neurogenins (Yoon and Gaiano, 2005). In OPCs, Hes1 and Hes5 are progressively downregulated during differentiation (Wang et al., 1998). Moreover, the expression of major myelin protein genes is increased in Hes5 null mice, and Hes5 has been shown to inhibit the level of transcription activators of myelin genes, such as Sox10 (Liu et al., 2006). Although the role of Notch signaling on OPC differentiation during remyelination remains controversial (Stidworthy et al., 2004), a recent study using a mouse line with specific deletion of Notch1 in oligodendroglial cells showed accelerated OPC differentiation and remyelination in the absence of Notch1 (Zhang et al., 2009). Additionally, Notch signaling has been implicated as a major contributor of remyelination failure in MS. Indeed, the reexpression of Jagged 1 by reactive astrocytes in chronic MS lesions (John et al., 2002) may activate Notch signaling in OPCs, thereby preventing their differentiation. The activation of Notch receptors in MS is also supported by upregulation of Hes5 in chronic lesions (John et al., 2002). Furthermore, it has been demonstrated that the binding of axonal contactin to Notch1 on OPCs in chronic MS lesions leads to the activation of the receptor and, consequently, to cleaved NICD. However, nuclear translocation of NICD, which is necessary for proper OPC differentiation and remyelination, does not occur, resulting in remyelination block in 
chronic MS lesions (Nakahara et al., 2009). By inducing OPC differentiation through the inhibition of Notch signaling, TFA-12 therefore has a remarkable remyelinating activity in experimental models of MS.

In summary, our study has revealed important insights into the activity of TFA-12 on neuroinflammation and remyelination in experimental models of MS, and opens new avenues for innovative therapies promoting myelin regeneration in demyelinating diseases.

\section{References}

Back SA, Tuohy TM, Chen H, Wallingford N, Craig A, Struve J, Luo NL, Banine F, Liu Y, Chang A, Trapp BD, Bebo BF Jr, Rao MS, Sherman LS (2005) Hyaluronan accumulates in demyelinated lesions and inhibits oligodendrocyte progenitor maturation. Nat Med 11:966-972. Medline

Borg J, Kesslak PJ, Cotman CW (1990) Peripheral administration of a longchain fatty alcohol promotes septal cholinergic neurons survival after fimbria-fornix transection. Brain Res 518:295-298. CrossRef Medline

Chang A, Tourtellotte WW, Rudick R, Trapp BD (2002) Premyelinating oligodendrocytes in chronic lesions of multiple sclerosis. N Engl J Med 346:165-173. CrossRef Medline

Compston A, Coles A (2008) Multiple sclerosis. Lancet 372:1502-1517. CrossRef Medline

Connor B, Dragunow M (1998) The role of neuronal growth factors in neurodegenerative disorders of the human brain. Brain Res Brain Res Rev 27:1-39. CrossRef Medline

Dawson MR, Polito A, Levine JM, Reynolds R (2003) NG2-expressing glial progenitor cells: an abundant and widespread population of cycling cells in the adult rat CNS. Mol Cell Neurosci 24:476-488. CrossRef Medline

Decker L, Lachapelle F, Magy L, Picard-Riera N, Nait-Oumesmar B, BaronVan Evercooren A (2005) Fibroblast growth factors in oligodendrocyte physiology and myelin repair. Ernst Schering Res Found Workshop 53: $39-59$.

Fancy SP, Baranzini SE, Zhao C, Yuk DI, Irvine KA, Kaing S, Sanai N, Franklin RJ, Rowitch DH (2009) Dysregulation of the Wnt pathway inhibits timely myelination and remyelination in the mammalian CNS. Genes Dev 23:1571-1585. CrossRef Medline

Fancy SP, Chan JR, Baranzini SE, Franklin RJ, Rowitch DH (2011) Myelin regeneration: a recapitulation of development? Annu Rev Neurosci 34: 21-43. CrossRef Medline

Franklin RJ, Ffrench-Constant C (2008) Remyelination in the CNS: from biology to therapy. Nat Rev Neurosci 9:839-855. CrossRef Medline

Genoud S, Lappe-Siefke C, Goebbels S, Radtke F, Aguet M, Scherer SS, Suter U, Nave KA, Mantei N (2002) Notchl control of oligodendrocyte differentiation in the spinal cord. J Cell Biol 158:709-718. CrossRef Medline

Grandbarbe L, Michelucci A, Heurtaux T, Hemmer K, Morga E, Heuschling P (2007) Notch signaling modulates the activation of microglial cells. Glia 55:1519-1530. CrossRef

Hobom M, Storch MK, Weissert R, Maier K, Radhakrishnan A, Kramer B, BährM, Diem R (2004) Mechanisms and time course of neuronal degeneration in experimental autoimmune encephalomyelitis. Brain Pathol 14:148-157. CrossRef Medline

Hohlfeld R, Kerschensteiner M, Meinl E (2007) Dual role of inflammation in CNS disease. Neurology 68:S58-S63; discussion S91-S96. CrossRef Medline

Hu QD, Ang BT, Karsak M, Hu WP, Cui XY, Duka T, Takeda Y, Chia W, Sankar N, Ng YK, Ling EA, Maciag T, Small D, Trifonova R, Kopan R, Okano H, Nakafuku M, Chiba S, Hirai H, Aster JC, et al. (2003) F3/ contactin acts as a functional ligand for Notch during oligodendrocyte maturation. Cell 115:163-175. CrossRef Medline

Huang JK, Jarjour AA, Nait Oumesmar B, Kerninon C, Williams A, Krezel W, Kagechika H, Bauer J, Zhao C, Baron-Van Evercooren A, Chambon P, Ffrench-Constant C, Franklin RJ (2011) Retinoid X receptor gamma signaling accelerates CNS remyelination. Nat Neurosci 14:45-53. CrossRef Medline

John GR, Shankar SL, Shafit-Zagardo B, Massimi A, Lee SC, Raine CS, Brosnan CF (2002) Multiple sclerosis: re-expression of a developmental pathway that restricts oligodendrocyte maturation. Nat Med 8:11151121. CrossRef Medline

Jones MV, Nguyen TT, Deboy CA, Griffin JW, Whartenby KA, Kerr DA, Calabresi PA (2008) Behavioral and pathological outcomes in MOG
35-55 experimental autoimmune encephalomyelitis. J Neuroimmunol 199:83-93. CrossRef Medline

Jurynczyk M, Jurewicz A, Bielecki B, Raine CS, Selmaj K (2005) Inhibition of Notch signaling enhances tissue repair in an animal model of multiple sclerosis. J Neuroimmunol 170:3-10. CrossRef Medline

Kapelusiak-Pielok M, Adamczewska-Goncarzewicz Z, Dorszewska J, Grochowalska A (2005) The protective action of alpha-tocopherol on the white matter lipids during moderate hypoxia in rats. Folia Neuropathol 43:103-108. Medline

Kieseier BC, Wiendl H, Hemmer B, Hartung HP (2007) Treatment and treatment trials in multiple sclerosis. Curr Opin Neurol 20:286-293. CrossRef Medline

Kotter MR, Setzu A, Sim FJ, Van Rooijen N, Franklin RJ (2001) Macrophage depletion impairs oligodendrocyte remyelination following lysolecithininduced demyelination. Glia 35:204-212. CrossRef Medline

Kryzhanovskiü GN, Vilkov GA, Stepanenko EM (1984) Protective action of antioxidant preparations on the development of experimental allergic encephalomyelitis in guinea pigs. Biull Eksp Biol Med 98:527-530. Medline

Liu A, Li J, Marin-Husstege M, Kageyama R, Fan Y, Gelinas C, CasacciaBonnefil P (2006) A molecular insight of Hes5-dependent inhibition of myelin gene expression: old partners and new players. EMBO J 25:48334842. CrossRef Medline

Louis JC, Magal E, Muir D, Manthorpe M, Varon S (1992) CG-4, a new bipotential glial cell line from rat brain, is capable of differentiating in vitro into either mature oligodendrocytes or type- 2 astrocytes. J Neurosci Res 31:193-204. CrossRef Medline

McCarthy KD, de Vellis J (1980) Preparation of separate astroglial and oligodendroglial cell cultures from rat cerebral tissue. J Cell Biol 85:890-902. Medline

Mi S, Miller RH, Tang W, Lee X, Hu B, Wu W, Zhang Y, Shields CB, Zhang Y, Miklasz S, Shea D, Mason J, Franklin RJ, Ji B, Shao Z, Chedotal A, Bernard F, Roulois A, Xu J, Jung V, et al. (2009) Promotion of central nervous system remyelination by induced differentiation of oligodendrocyte precursor cells. Ann Neurol 65:304-315. CrossRef Medline

Morga E, Faber C, Heuschling P (2000) Stimulation of endothelin B receptor modulates the inflammatory activation of rat astrocytes. J Neurochem 74:603-612. CrossRef Medline

Muller T, Grandbarbe L, Morga E, Heuschling P, Luu B (2004) Tocopherol long chain fatty alcohols decrease the production of TNF-alpha and NO radicals by activated microglial cells. Bioorg Med Chem Lett 14:60236026. CrossRef Medline

Murphy S, Lin HL, Park SK (1995) Cytokine-induced expression of type II nitric oxide synthase in astrocytes is downregulated by ATP and glutamate. Glia 15:77-82. CrossRef Medline

Nait Oumesmar B, Vignais L, Duhamel-ClérinE, Avellana-Adalid V, Rougon G, Baron-Van Evercooren A (1995) Expression of the highly polysialylated neural cell adhesion molecule during postnatal myelination and following chemically induced demyelination of the adult mouse spinal cord. Eur J Neurosci 7:480-491. CrossRef Medline

Nakahara J, Kanekura K, Nawa M, Aiso S, Suzuki N (2009) Abnormal expression of TIP30 and arrested nucleocytoplasmic transport within oligodendrocyte precursor cells in multiple sclerosis. J Clin Invest 119:169-181. CrossRef Medline

Nash B, Thomson CE, Linington C, Arthur AT, McClure JD, McBride MW, Barnett SC (2011) Functional duality of astrocytes in myelination. J Neurosci 14:13028-13038. CrossRef Medline

Okabe M, Ikawa M, Kominami K, Nakanishi T, Nishimune Y (1997) "Green mice" as a source of ubiquitous green cells. FEBS Lett 407:313319. CrossRef Medline

Park HC, Boyce J, Shin J, Appel B (2005) Oligodendrocyte specification in zebrafish requires notch-regulated cyclin-dependent kinase inhibitor function. J Neurosci 25:6836-6844. CrossRef Medline

Parras CM, Hunt C, Sugimori M, Nakafuku M, Rowitch D, Guillemot F (2007) The proneural gene Mash1 specifies an early population of telencephalic oligodendrocytes. J Neurosci 27:4233-4242. CrossRef Medline

Recks MS, Addicks K, Kuerten S (2011) Spinal cord histopathology of MOG peptide 35-55-induced experimental autoimmune encephalomyelitis is time- and score-dependent. Neurosci Lett 494:227-231. CrossRef Medline

Reynolds R, Dawson M, Papadopoulos D, Polito A, Di Bello IC, Pham-Dinh D, Levine J (2002) The response of NG2-expressing oligodendrocyte 
progenitors to demyelination in MOG-EAE and MS. J Neurocytol 31: 523-536. CrossRef Medline

Ridet JL, Malhotra SK, Privat A, Gage FH (1997) Reactive astrocytes: cellular and molecular cues to biological function. Trends Neurosci 20:570-577. CrossRef Medline

Selmaj K, Shafit-Zagardo B, Aquino DA, Farooq M, Raine CS, Norton WT, Brosnan CF (1991) Tumor necrosis factor-induced proliferation of astrocytes from mature brain is associated with down-regulation of glial fibrillary acidic protein mRNA. J Neurochem 57:823-830. CrossRef Medline

Setzu A, Lathia JD, Zhao C, Wells K, Rao MS, Ffrench-Constant C, Franklin RJ (2006) Inflammation stimulates myelination by transplanted oligodendrocyte precursor cells. Glia 54:297-303. CrossRef Medline

Stidworthy MF, Genoud S, Li WW, Leone DP, Mantei N, Suter U, Franklin RJ (2004) Notch1 and Jagged 1 are expressed after CNS demyelination, but are not a major rate-determining factor during remyelination. Brain 127: 1928-1941. CrossRef Medline

Sugimori M, Nagao M, Bertrand N, Parras CM, Guillemot F, Nakafuku M (2007) Combinatorial actions of patterning and HLH transcription factors in the spatiotemporal control of neurogenesis and gliogenesis in the developing spinal cord. Development 134:1617-1629. CrossRef Medline

Thoenen H, Sendtner M (2002) Neurotrophins: from enthusiastic expectations through sobering experiences to rational therapeutic approaches. Nat Neurosci [Suppl] 5:1046-1050. CrossRef Medline
Torkildsen Ø, Løken-Amsrud KI, Wergeland S, Myhr KM, Holmøy T (2013) Fat-soluble vitamins as disease modulators in multiple sclerosis. Acta Neurol Scand Suppl 196:16-23. CrossRef Medline

Trapp BD, Nave KA (2008) Multiple sclerosis: an immune or neurodegenerative disorder? Annu Rev Neurosci 31:247-269. CrossRef Medline

Wang S, Sdrulla AD, diSibio G, Bush G, Nofziger D, Hicks C, Weinmaster G, Barres BA (1998) Notch receptor activation inhibits oligodendrocyte differentiation. Neuron 21:63-75. CrossRef Medline

Williams A, Piaton G, Lubetzki C (2007) Astrocytes: friends or foes in multiple sclerosis? Glia 55:1300-1312. CrossRef Medline

Xie Y, Longo FM (2000) Neurotrophin small-molecule mimetics. Prog Brain Res 128:333-347. CrossRef Medline

Ye F, Chen Y, Hoang T, Montgomery RL, Zhao XH, Bu H, Hu T, Taketo MM, van Es JH, Clevers H, Hsieh J, Bassel-Duby R, Olson EN, Lu QR (2009) HDAC1 and HDAC2 regulate oligodendrocyte differentiation by disrupting the beta-catenin-TCF interaction. Nat Neurosci 12:829-838. CrossRef Medline

Yoon K, Gaiano N (2005) Notch signaling in the mammalian central nervous system: insights from mouse mutants. Nat Neurosci 8:709-715. CrossRef Medline

Zhang Y, Argaw AT, Gurfein BT, Zameer A, Snyder BJ, Ge C, Lu QR, Rowitch DH, Raine CS, Brosnan CF, John GR (2009) Notch1 signaling plays a role in regulating precursor differentiation during CNS remyelination. Proc Natl Acad Sci U S A 106:19162-19167. CrossRef Medline 